\title{
FINTECH SYARIAH SEBAGAI FAKTOR PENDORONG PENINGKATAN INKLUSIVITAS USAHA MIKRO KECIL DAN MENENGAH DI INDONESIA
}

\author{
Alen Suci Marlina ${ }^{1}$ \& Nur Fatwa ${ }^{2}$ \\ ${ }^{1 \& 2}$ Program Pascasarjana Kajian Timur Tengah, Universitas Indonesia \\ Email : alenmarlina@yahoo.com,nurfatwa@ui.ac.id
}

\begin{abstract}
ABSTRAK
Kehadiran financial technology (fintech) syariah sebagai lembaga keuangan yang kredibel diharapkan mampu membantu permasalahan yang seringkali dihadapi Usaha Mikro Kecil dan Menengah (UMKM) di Indonesia. Penelitian ini menghasilkan kesimpulan bahwa fintech syariah berperan sebagai faktor pendorong dalam meningkatkan inklusivitas Usaha Mikro Kecil dan Menengah (UMKM) di Indonesia. Kehadiran industri fintech syariah dapat mengatasi permasalahan Usaha Mikro Kecil dan Menengah (UMKM) di Indonesia, terutama terkait kebutuhan pembiayaan, kemudahan proses transaksi, perluasan akses pasar, dan kemudahan dalam penyusunan laporan keuangan.
\end{abstract}

Kata Kunci : Financial Technology Syariah, UMKM, Keuangan Inklusif.

\begin{abstract}
The presence of sharia financial technology (fintech) as a credible financial institution is expected to be able to help the obstacles that are often faced by Micro Small and Medium Enterprises (MSMEs) in Indonesia. This study concludes that sharia fintech acts as a catalyst in encouraging the financial inclusion of Micro Small and Medium Enterprises (MSMEs) in Indonesia. The presence of the sharia fintech industry can overcome the drawbacks of Micro Small and Medium Enterprises (MSMEs) in Indonesia, especially related to financing needs, ease of transaction processing, expansion of market access, and ease of preparation of financial reports.
\end{abstract}

Keywords : Sharia Financial Technology, MSMEs, Financial Inclusion. 


\section{PENDAHULUAN}

Dalam Masterplan Ekonomi Syariah Indonesia 2019-2024, disebutkan mengenai empat strategi utama yang akan diimplementasikan dalam 5 (lima) tahun ke depan untuk mendorong perkembangan Ekonomi Syariah di Indonesia. Keempat strategi tersebut yaitu: penguatan Halal Value Chain, penguatan sektor keuangan syariah, penguatan Usaha Mikro Kecil dan Menengah (UMKM), dan penguatan ekonomi digital. Tiga dari empat strategi utama tersebut relevan dengan penelitian ini, yaitu terkait strategi penguatan sektor keuangan syariah, Usaha Mikro Kecil dan Menengah (UMKM), dan ekonomi digital. Penguatan Usaha Mikro Kecil dan Menengah (UMKM) didasarkan pada pertimbangan bahwa walaupun jika dilihat secara individu, kuantitas perekonomian Usaha Mikro Kecil dan Menengah (UMKM) tidak signifikan, namun secara sektoral, Usaha Mikro Kecil dan Menengah (UMKM) merupakan tulang punggung perekonomian nasional, baik dari sisi jumlah maupun kontribusinya.

Berdasarkan data Kementerian Koperasi dan Usaha Kecil dan Menengah Republik Indonesia terakhir di tahun 2019, Usaha Mikro Kecil dan Menengah (UMKM) di Indonesia berjumlah lebih dari 65 juta unit dengan pangsa sebesar 99,99 persen. Dari sifatnya yang merupakan usaha padat karya, Usaha Mikro Kecil dan Menengah (UMKM) berhasil menyerap 96,92 persen tenaga kerja di Indonesia. Selain itu, Usaha Mikro Kecil dan Menengah (UMKM) pun menyumbang sebesar 60,51 persen Produk Domestik Bruto (PDB) nasional. Dengan demikian, sektor ini pasti memiliki signifikansi dalam memperkuat ekonomi syariah di Indonesia.

Dari sisi sektor keuangan, Muzdalifa et al, (2018) menyatakan bahwa Indonesia memiliki potensi dan kompetensi untuk mengembangkan industri fintech, terlihat dari perkembangannya yang relatif cepat dan konsisten. Berkembangnya industri fintech, khususnya fintech syariah, diharapkan mampu memberikan dorongan bagi peningkatan inklusivitas keuangan Usaha Mikro Kecil dan Menengah (UMKM) di Indonesia. Harapan ini dilatarbelakangi oleh permasalahan klasik yang sering dihadapi Usaha Mikro Kecil dan Menengah (UMKM) yaitu permasalahan permodalan. Hambatan lain sebagaimana disampaikan oleh Ardiansyah \& Sawitri (2019) adalah hambatan dalam memasarkan produk. Selain itu, Sutarmin dan Susanto (2017) juga menyebutkan bahwa inefisiensi transaksi juga menjadi kendala yang dihadapi Usaha Mikro Kecil dan Menengah (UMKM).

Fintech yang tumbuh di berbagai sektor usaha di Indonesia mempermudah Usaha Mikro Kecil dan Menengah (UMKM) dalam menjalankan usahanya, baik dari sisi akses pembiayaan, perluasan akses pasar, simplifikasi sistem pembayaran, dan kemudahan dalam menyusun laporan keuangan. Berdasarkan penelitian Milian et al, (2019) dan Rizvi et al, (2018), berbagai kemudahan yang diberikan oleh industri fintech disebabkan faktor fleksibilitas, keamanan, efisiensi, dan peluang yang lebih tinggi dibandingkan dengan layanan keuangan tradisional. Dengan adanya kemudahan operasional tersebut, Usaha Mikro Kecil dan Menengah (UMKM) yang disebut sebagai sumber pertumbuhan ekonomi baru dapat lebih fokus dalam menjalankan usahanya sehingga pada akhirnya akan meningkatkan daya saing Usaha Mikro Kecil dan Menengah (UMKM) dalam perekonomian nasional ataupun global.

Keterbatasan yang dihadapi Usaha Mikro Kecil dan Menengah (UMKM) sebagaimana disebutkan sebelumnya menjadi faktor penghambat dalam pengembangan usahanya. Pemerintah dan otoritas terkait selalu berupaya agar Usaha Mikro Kecil dan Menengah (UMKM) dapat terus memperoleh fasilitasi yang dapat mempermudah usahanya. $\mathrm{Di}$ tengah perkembangan teknologi yang pesat, kehadiran industri fintech membawa harapan baru bagi Usaha Mikro Kecil dan Menengah (UMKM). 
Sebagai salah satu bentuk dukungan dan fasilitas Pemerintah terhadap perkembangan industri fintech, otoritas terkait yaitu Otoritas Jasa Keuangan (OJK) dan Bank Indonesia (BI), menerbitkan beberapa ketentuan pendukung terkait yaitu sebagai berikut:

1. Peraturan No.1/POJK.07/2013

OJK

(POJK) Perlindungan Konsumen Sektor Jasa Keuangan.

2. POJK No.77/POJK.01/2016 tentang Layanan Pinjam Meminjam Uang Berbasis Teknologi Informasi.

3. POJK Nomor 13/POJK.02/2018 tentang Inovasi Keuangan Digital di Sektor Jasa Keuangan.

4. Peraturan Bank Indonesia (PBI) No.18/40/PBI/2016 tentang Penyelenggaraan Pemrosesan Transaksi Pembayaran.

5. Surat Edaran Bank Indonesia No.18/22/DKSP/2016 tentang Penyelenggaraan Layanan Keuangan Digital.

6. PBI No.19/12/PBI/2017 tentang Penerapan Teknologi Keuangan.

7. PBI No.20/6/PBI/2018 tentang Uang Elektronik.

Lebih jauh lagi, Bank Indonesia terus mendorong, memperkuat, dan memperluas inovasi untuk meningkatkan ekonomi keuangan digital. Upaya tersebut diwujudkan dengan peluncuran Sandbox 2.0 sebagai penyempurnaan dari regulatory sandbox, yang mencakup tiga fungsi, yaitu:

1. Innovation lab, yang merupakan sarana pengembangan inovasi yang belum digunakan atau telah digunakan di industri sistem pembayaran namun baru dalam lingkup terbatas.

2. Industrial sandbox, yaitu inovasi yang telah digunakan di industri sistem pembayaran dan perlu diperluas penggunaannya.
3. Regulatory sandbox, sebagai suatu sarana inovasi terhadap kebijakan atau ketentuan sistem pembayaran.

\section{TINJAUAN PUSTAKA}

\section{Financial Technology}

Fintech merupakan bidang usaha yang menyediakan jasa keuangan dan perbankan melalui pemanfaatan teknologi. Kehadiran fintech bertujuan untuk mempermudah akses masyarakat agar dapat terhubung dengan produk dan jasa keuangan, termasuk melakukan transaksi keuangan. Selain itu, kehadiran fintech juga diharapkan dapat meningkatkan literasi keuangan masyarakat (Ozili, 2018).

Menurut Hsueh \& Kuo (2017), terdapat tiga jenis layanan fintech yaitu:

1. Sistem pembayaran pihak ketiga

Seperti electronic commerce (EC) cross border, online-to-offline $(\mathrm{O} 2 \mathrm{O})$, sistem pembayaran dengan menggunakan perangkat seluler, dan platform yang menyediakan layanan seperti pembayaran dan transfer bank.

2. Pinjaman dengan metode Peer-to-Peer (P2P)

Adalah platform yang mempertemukan kreditur dan debitur (terutama individual dan UMKM) untuk saling memenuhi kebutuhan mereka.

\section{Crowdfunding,}

Yaitu jenis fintech yang mengumpulkan dukungan finansial dari masyarakat, baik online maupun offline, untuk membiayai proyek tertentu.

Sistem keuangan syariah digunakan untuk mengelola keuangan yang menggunakan prinsip dasar syariah. Prinsip dasar syariah diambil dari Al-Quran dan juga Sunnah yang menjadi pegangan umat Muslim dimanapun berada. Di Indonesia khususnya, prinsip syariah adalah hukum Islam dalam kegiatan perbankan dan 
keuangan berdasarkan fatwa yang dikeluarkan oleh lembaga yang memiliki wewenang. Adapun perbedaan antara fintech konvensional dan syariah dapat dilihat dari beberapa hal yaitu:

1. Dasar-dasar yang dianut

Fintech syariah menggunakan syariat Islam sebagai dasar layanan/ operasional keuangan mereka. Dalam menjalani kegiatan usahanya, fintech syariah harus sesuai dengan peraturan Otoritas Jasa dan Keuangan (OJK) No.77/POJK.01/2016 tanggal 26 Desember 2016 tentang Layanan Pinjam Meminjam Uang Berbasis Teknologi Informasi. Selain Otoritas Jasa dan Keuangan (OJK), fintech berbasis syariah juga harus menaati fatwa Dewan Syariah Nasional Majelis Ulama Indonesia (DSNMUI) No.117/DSN-MUI/II/2018 tentang Layanan Pembiayaan Berbasis Teknologi Informasi Berdasarkan Prinsip Syariah.

2. Bunga

Fintech syariah seperti halnya prinsip syariah, tidak mengenal sistem bunga yang mengandung unsur riba dan tidak sesuai dengan ajaran Islam.

3. Akad

Pembiayaan pada fintech syariah dilakukan berdasarkan beberapa akad yaitu:

a. Murabahah, yaitu akad jual beli di mana perusahaan fintech syariah menjadi seorang pembeli atas produk yang diinginkan nasabah. Kemudian, peminjam akan menjual produk tersebut kepada nasabah dengan jumlah keuntungan yang sudah disetujui sebelumnya.

b. Ijarah Wa Iqtina, yaitu akad sewa. Seperti akad Murabahah, pada akad Ijarah Wa Iqtina penyelanggara fintech Syariah menjadi pembeli atas barang yang diinginkan oleh nasabah. Lalu, peminjam akan menyewakan barang tersebut yang di kemudian hari dapat dibeli oleh nasabah. Barang tersebut terdapat dalam status sewa dengan kurun waktu tertentu sampai berpindah kepemilikan.

c. Musyarakah Mutanaqishah, yaitu program pembiayaan yang berasal dari penyelenggara fintech dan nasabah. Masing-masing akan memberikan modal untuk produk tertentu. Nantinya, nasabah dapat membeli bagian yang dimiliki oleh penyelenggara fintech Syariah. Jadi, nasabah dapat memiliki hak penuh atas kepemilikan produk tersebut.

\section{Inklusif}

The World Bank mendefinisikan inklusi keuangan sebagai suatu kondisi dimana individu dan perusahaan memiliki akses kepada produk dan layanan keuangan yang bermanfaat dan terjangkau yang dapat memenuhi kebutuhan mereka, seperti transaksi keuangan, pembayaran, tabungan, kredit, dan asuransi yang disampaikan dengan cara yang bertanggung jawab dan berkelanjutan. Akses yang efektif juga meliputi layanan yang nyaman dan bertanggung jawab, pada harga yang terjangkau untuk masyarakat dan berkelanjutan untuk penyedia. Financial inclusion sendiri disebutkan menjadi kunci mengurangi kemiskinan dan meningkatkan kesejahteraan rakyat.

Di Indonesia sendiri, berdasarkan Peraturan Presiden Nomor 82 Tahun 2016 tentang Strategi Nasional Keuangan Inklusif, inklusi keuangan didefinisikan sebagai sebuah kondisi dimana setiap anggota masyarakat mempunyai akses terhadap berbagai layanan keuangan formal yang berkualitas, tepat waktu, lancar, dan aman dengan biaya terjangkau sesuai dengan kebutuhan dan kemampuan masing-masing. 
Usaha Mikro, Kecil, dan Menengah (UMKM)

Usaha Mikro Kecil dan Menengah (UMKM) merupakan usaha ekonomi produktif yang dimiliki perorangan maupun badan usaha sesuai dengan kriteria yang ditetapkan oleh Undang-Undang No. 20 tahun 2008 tentang Usaha Mikro, Kecil, dan Menengah. Dalam Undang-undang tersebut dijelaskan bahwa:

1. Usaha Mikro, adalah usaha yang memiliki kekayaan bersih maksimal sebesar Rp. 50.000.000,00 (lima puluh juta rupiah) tidak termasuk bangunan dan tanah tempat usaha, atau memiliki omset tahunan maksimal sebesar Rp. 300.000.000,00 (tiga ratus juta rupiah).

2. Usaha Kecil, adalah usaha yang memiliki kekayaan bersih lebih dari Rp. 50.000.000,00 (lima puluh juta rupiah) sampai dengan maksimal sebesar Rp. 500.000.000,00 (lima ratus juta rupiah) tidak termasuk tanah dan bangunan tempat usaha, atau memiliki omset tahunan lebih dari Rp. 300.000.000,00 (tiga ratus juta rupiah) sampai dengan maksimal sebesar Rp. 2.500.000.000,00 (dua milyar lima ratus juta rupiah).

3. Usaha Menengah, adalah usaha yang memiliki kekayaan bersih lebih dari Rp. 500.000.000,00 (lima ratus juta rupiah) sampai dengan maksimal sebesar Rp10.000.000.000,00 (sepuluh milyar rupiah) tidak termasuk tanah dan bangunan tempat usaha, atau memiliki omset tahunan lebih dari Rp. 2.500.000.000,00 (dua milyar lima ratus juta rupiah) sampai dengan maksimal sebesar Rp. 50.000.000.000,00 (lima puluh milyar rupiah).

\section{METODE PENELITIAN}

Penelitian ini menggunakan analisis deskriptif dengan pendekatan kualitatif. Penelitian deskriptif digunakan untuk mendeskripsikan fintech, inklusif, dan Usaha
Mikro Kecil dan Menengah (UMKM) di Indonesia, sedangkan pendekatan kualitatif digunakan untuk menganalisis peranan fintech syariah dalam meningkatkan inklusivitas Usaha Mikro Kecil dan Menengah (UMKM) di Indonesia, sekaligus permasalahan yang dihadapi Usaha Mikro Kecil dan Menengah (UMKM) Indonesia yang dapat diminimalisir melalui kehadiran industri fintech. Sumber data diperoleh melalui studi pustaka berupa hasil penelitian dan pernyataan dari berbagai ahli yang dipublikasikan. Hasil penelitian yang dijadikan acuan adalah yang telah dipublikasikan di jurnal atau prosiding terindeks.

Teknik analisis data dilakukan dengan terlebih dahulu melakukan triangulasi sumber data untuk mendapatkan data yang benar-benar kredibel. Data yang dianggap kredibel kemudian disintesis untuk memperoleh suatu kesimpulan sehingga tercapai pemahaman yang menyeluruh.

\section{HASIL DAN PEMBAHASAN}

Usaha Mikro Kecil dan Menengah (UMKM) sebagai sektor usaha yang dari sisi kuantitas dan kontribusinya sangat penting bagi perekonomian nasional, dalam perkembangan usahanya seringkali menemui kendala. Sebagaimana disebutkan oleh Wang (2016), Sharma dan Gounder (2012), salah satu kendala utama utama yang dihadapi Usaha Mikro Kecil dan Menengah (UMKM) adalah akses pembiayaan yang sulit diperoleh dari perbankan tradisional sebagai lembaga keuangan karena banyaknya persyaratan yang harus dipenuhi oleh calon debitur, termasuk Usaha Mikro Kecil dan Menengah (UMKM).

Menurut Temelkov dan Samonikov (2018), keengganan atau ketidaksanggupan perbankan tradisional dalam menyalurkan pembiayaan kepada Usaha Mikro Kecil dan Menengah (UMKM) menjadi kesempatan untuk mengembangkan inovasi berupa alternatif sumber pembiayaan berbasis teknologi. 
Untuk mendukung usahanya, Usaha Mikro Kecil dan Menengah (UMKM) biasanya mengandalkan sumber pembiayaan dari lingkungan terdekatnya, yaitu dana pribadi, keluarga, dan teman. Dana yang terbatas tersebut tentunya hanya dapat mendukung pertumbuhan awal Usaha Mikro Kecil dan Menengah (UMKM), namun tidak akan cukup untuk memenuhi kebutuhan untuk mengembangkan usahanya. Untuk dapat naik ke level usaha yang lebih baik, Usaha Mikro Kecil dan Menengah (UMKM) berupaya untuk memperoleh pembiayaan lain, antara lain dari lembaga keuangan seperti perbankan tradisional.

Berdasakan World Economic Forum (2005), krisis ekonomi yang terjadi selama periode 2007-2008 memberikan dampak pada pembiayaan Usaha Mikro Kecil dan Menengah (UMKM). Regulator perbankan memperketat kebijakan pemberian kredit oleh perbankan kepada jenis pinjaman tertentu dan kategori debitur, termasuk kebijakan terkait permodalan perbankan. Hal ini menjadikan perbankan tradisional semakin enggan untuk menyalurkan pembiayaan kepada sektor-sektor yang dinilai memiliki portfolio resiko tinggi, termasuk Usaha Mikro Kecil dan Menengah (UMKM). Perbankan yang tetap menyalurkan pembiayaan kepada sektorsektor yang beresiko pun cenderung akan menetapkan suku bunga yang lebih tinggi dibandingkan dengan pembiayaan ke sektor yang dinilai relatif aman.

Namun demikian, tidak semua perbankan menghindari penyaluran pembiayaan kepada Usaha Mikro Kecil dan Menengah (UMKM), terutama perbankan yang operasional usahanya memang memiliki kekhususan dalam pemberian pembiayaan kepada Usaha Mikro Kecil dan Menengah (UMKM). Namun demikian terdapat Usaha Mikro Kecil dan Menengah (UMKM) dengan karakteristik tertentu sebagaimana penelitian yang dilakukan Vasilescu (2014), yang cenderung dihindari oleh perbankan dalam memberikan pembiayaan, yaitu Usaha Mikro Kecil dan Menengah (UMKM) yang memiliki yaitu:

1. Kondisi keuangan atau permodalan yang lemah.

2. Tingkat diversifikasi usaha yang rendah.

3. Peringkat kredit yang rendah atau bahkan tidak memiliki peringkat sama sekali.

4. Ketergantungan tinggi pada pembiayaan dalam menjalankan usahanya.

5. Akses pembiayaan atau keuangan yang terbatas.

6. Agunan yang tidak memadai atau bahkan tidak memiliki agunan sama sekali

7. Biaya transaksi yang lebih tinggi dibandingkan jenis usaha serupa.

Pada tahun 2019 Price Water House Coopers melakukan survei yang menghasilkan kesimpulan bahwa 74\% Usaha Mikro Kecil dan Menengah (UMKM) di Indonesia belum memperoleh akses keuangan. Hambatan ini terutama dikarenakan Usaha Mikro Kecil dan Menengah (UMKM) tidak dapat memenuhi persyaratan yang diminta oleh perbankan.

Berbeda dengan perusahaan besar yang dapat dengan mudah memperoleh akses terhadap produk dan jasa keuangan yang dikeluarkan oleh perbankan domestik maupun internasional, Usaha Mikro Kecil dan Menengah (UMKM) hanya dapat mengandalkan sektor perbankan tradisional dalam lingkup domestik. Hal inilah yang membuat Usaha Mikro Kecil dan Menengah (UMKM) seringkali mencari produk dan jasa keuangan alternatif selain perbankan tradisional untuk memenuhi kebutuhan pembiayaan usaha mereka yang semakin meningkat. Di sisi lain, terdapat perkembangan teknologi keuangan (financial technology fintech), yang menggabungkan industri keuangan dengan teknologi 
informasi terkini seperti big data, cloud computing, dan artificial intelligence.

Industri fintech dipandang sebagai lembaga intermediasi yang lebih inovatif karena dapat dengan mudah menghubungkan pihak yang membutuhkan pembiayaan dengan investor di dalam satu platform. Menurut Winarto (2020), dengan inovasi teknologi yang diimplementasikan industri fintech dalam melaksanakan operasional usahanya, akses Usaha Mikro Kecil dan Menengah (UMKM) terhadap produk dan jasa keuangan akan menjadi lebih efisiensi.

Selain permasalahan akses pembiayaan, kendala lain yang sering dihadapi Usaha Mikro Kecil dan Menengah (UMKM) adalah transaksi tunai dan pembayaran yang tidak efisien melalui bank tradisional. Transaksi tunai masih sangat dominan di kalangan Usaha Mikro Kecil dan Menengah (UMKM), sebagaimana dijelaskan oleh Sutarmin dan Susanto (2017), bahwa transaksi non tunai Indonesia relatif rendah yaitu hanya sebesar $0,6 \%$ dari total transaksi ritel non tunai, jauh di bawah Singapura yang mencapai $44,5 \%$. Adapun Malaysia sebagai negara tetangga Indonesia mencatatkan persentasi transaksi non tunai sebesar $7,7 \%$.

Fintech Singapore di tahun 2018 menyampaikan data bahwa dari sembilan jenis fintech yaitu: Peer-to-peer (P2P) lending, sistem pembayaran, manajemen investasi dan keuangan, pembanding harga, insurtech, crowdfunding, Point of Sales (POS) system, cryptocurrency dan blockchain, serta akuntansi, yang mendominasi adalah sistem pembayaran (payment) sebesar 38\% dan Peer-to-peer (P2P) lending sebesar 31\%. Namun demikian menurut Asosiasi Fintech Syariah Indonesia (AFSI) (2018) yang anggotanya tidak hanya terdiri dari fintech syariah, namun juga termasuk institusi, akademisi, dan asosiasi yang memiliki kegiatan terkait fintech syariah, sampai dengan saat ini, komposisi industri fintech syariah di Indonesia masih didominasi oleh sektor usaha lending.
Fintech memiliki peran besar dalam mengakselerasi inklusi keuangan Usaha Mikro Kecil dan Menengah (UMKM) di Indonesia yang belum memperoleh akses keuangan dari lembaga keuangan konvensional seperti perbankan. Hal tersebut seperti diungkapkan Fenwick et al, (2017), karena industri fintech memiliki dukungan teknologi untuk menilai kelayakan kredit atau pembiayaan bagi konsumennya.

Data hasil survei DSInnovative yang dilakukan pada 2021 menunjukkan bahwa $25,71 \%$ responden (yang seluruhnya merupakan pelaku UMKM) menyatakan bahwa fintech dengan jenis Peer-to-peer (P2P) lending merupakan tipe pembiayaan yang akan lebih dipilih dibandingkan tipe lainnya.

Saat ini, Otoritas Jasa dan Keuangan sebagai salah satu otoritas yang mengatur lembaga keuangan baru merilis data untuk fintech berbentuk Peer-to-peer (P2P) lending. Pertumbuhan akumulasi jumlah pinjaman perusahaan Peer-to-peer (P2P) lending di Indonesia mengalami peningkatan yang signifikan selama tahun 2019. Berdasarkan data Otoritas Jasa dan Keuangan (OJK), pada bulan Februari 2019, tercatat akumulasi jumlah pinjaman sebesar Rp. 26 triliun, meningkat sebesar $642 \%$ dibandingkan Februari 2018 yang hanya Rp. 3,5 triliun.

Sementara dari sisi jumlah, pada data Juli 2021 terdapat 121 perusahaan fintech yang terdaftar di Otoritas Jasa dan Keuangan (OJK), dan 9 diantaranya merupakan fintech syariah dengan total aset sebesar Rp.107,33 miliar. Total aset perusahaan fintech syariah tersebut mengalami peningkatan yang cukup pesat sebesar $73 \%$ jika dibandingkan dengan data pada Juli 2020 yaitu Rp. 61,89 miliar.

Industri fintech syariah memang masih dikategorikan sebagai industri yang baru jika dibandingkan dengan fintech konvensional, namun demikian perkembangannya dilihat dari sisi aset relatif cepat. Berdasarkan data Otoritas Jasa dan Keuangan OJK tahun 2021 trend 
perkembangan aset industri fintech syariah fintech konvensional, hal ini dapat dilihat meningkat pesat dibandingkan dengan pada gambar berikut ini:

\section{Gambar 1. Perkembangan Aset Fintech Konvensional dan Syariah}

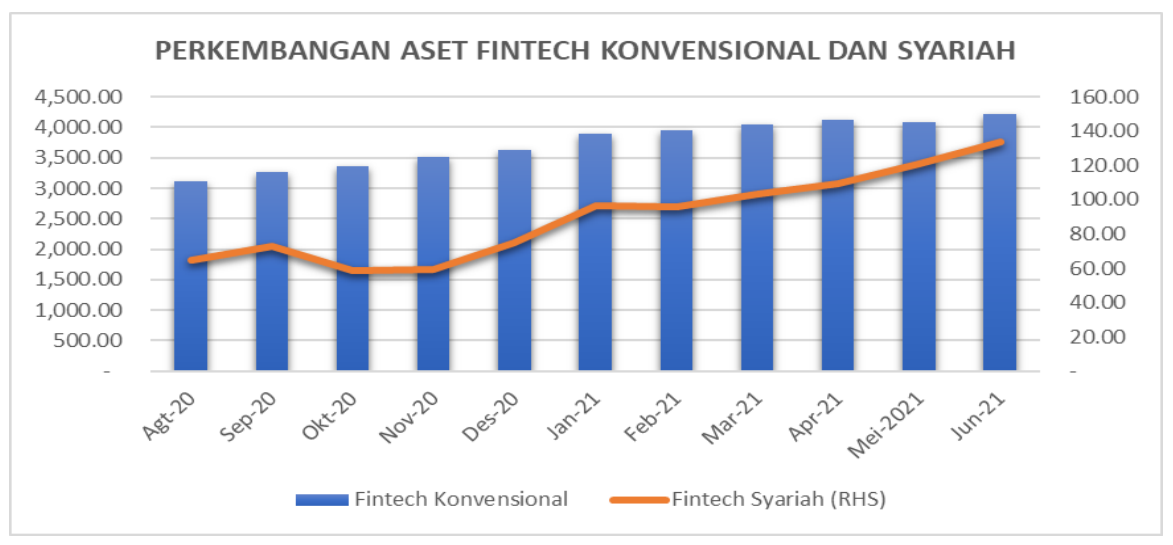

Sumber: Otoritas Jasa dan Keuangan (2021)

Dari gambar di atas diketahui bahwa pada triwulan II tahun 2021, pertumbuhan aset fintech syariah mencapai 29,23 \%, sementara fintech konvensional hanya 4,45 $\%$. Perkembangan industri fintech syariah ke depannya diperkirakan masih akan terus mengalami peningkatan mengingat tingginya dukungan dari lembaga keuangan syariah dan juga bonus demografi Indonesia sebagai negara dengan populasi muslim terbesar di dunia.

Sejalan dengan perkembangan jumlah pelaku dan aset industri fintech syariah, Asosiasi Fintech Pendanaan Bersama Indonesia (AFPI) mencatat akumulasi pembiayaan yang dilakukan oleh fintech syariah pada posisi Desember 2020 mencapai Rp 1,7 triliun. Berdasarkan kajian yang disusun oleh DSResearch dan AFPI pada 2020, diketahui bahwa mayoritas peminjam aktif industri fintech syariah adalah para pekerja dan Usaha Mikro Kecil dan Menengah (UMKM). Adapun data ini diperoleh berdasarkan survei yang dilakukan kepada 10 perusahaan fintech syariah.

World Bank Group (2020) pun menyatakan hal yang senada terkait perkembangan fintech syariah, yaitu industri ini memiliki potensi pertumbuhan yang besar karena di negara-negara yang berpenduduk mayoritas Muslim, termasuk Indonesia, dan tingkat inklusivitas masyarakatnya terhadap layanan perbankan masih rendah.
Usaha Mikro Kecil dan Menengah (UMKM) menjadi tulang punggung perekonomian nasional yang dapat bertahan di tengah krisis ekonomi yang dialami Indonesia. Namun demikian, berbeda dengan krisis sebelumnya, dampak krisis yang dialami akibat pandemi COVID-19, sangat dirasakan oleh Usaha Mikro Kecil dan Menengah (UMKM). Dampak negatif pandemi terhadap Usaha Mikro Kecil dan Menengah (UMKM) tersebut memiliki efek monopoli juga kepada industri fintech syariah karena hampir 100 persen pembiayaannya disalurkan kepada Usaha Mikro Kecil dan Menengah (UMKM). Menurut Kementerian Koperasi dan Usaha Kecil dan Menengah Republik Indonesia, sekitar 30 \% Usaha Mikro Kecil dan Menengah (UMKM) mengalami dampak negatif pada usahanya, sedangkan yang terdampak namun dapat berinovasi mencapai sekitar 50-70 \%. Sebagian besar Usaha Mikro Kecil dan Menengah (UMKM) yang bertahan tersebut memanfaatkan platform digital.

Kesadaran Usaha Mikro Kecil dan Menengah (UMKM) untuk dapat memanfaatkan ekosistem digital inilah yang menjadi salah satu alasan industri fintech dapat berkembang walaupun secara nasional pertumbuhan pembiayaan mengalami penurunan. Ekonomi makro yang tumbuh melambat membawa dampak pula pada 
pertumbuhan aset fintech syariah, walaupun efek negatif tersebut masih dapat diminimalisir oleh tingginya kesadaran masyarakat untuk menggunakan layanan fintech syariah. Hal tersebut berkorelasi positif pada pertumbuhan aset fintech syariah walaupun tidak secepat dibandingkan sebelum pandemi.

Dalam Masterplan Ekonomi Syariah Indonesia 2019-2024 disebutkan bahwa pertumbuhan transaksi digital melalui aplikasi mobile dinilai potensial untuk meningkatkan pertumbuhan fintech syariah. Hal ini dikarenakan aplikasi mobile akan lebih mudah untuk diakses oleh masyarakat, terutama Usaha Mikro Kecil dan Mengah (UMKM) karena berdasarkan Badan Pusat Statistik tahun 2020 dan datareportal.com tahun 2020, dari 270 juta penduduk Indonesia, sebanyak 190 juta diantaranya merupakan penduduk dengan usia 15-64 tahun dan mayoritasnya (sebesar $124 \%$, yang berarti satu penduduk memiliki lebih dari satu mobile phone) menggunakan mobile connection. Hal ini menunjukkan bahwa potensi digital Indonesia masih sangat tinggi.

Namun demikian, terdapat tantangan dari sisi faktor produksi, yaitu kesiapan masing-masing daerah di Indonesia masih belum merata, misalnya ketersediaan sarana dan prasarana penunjang seperti akses jaringan, internet, dan listrik.

Perkembangan digitalisasi yang mendukung aktivitas perekonomian di Indonesia, terutama fintech syariah, memiliki potensi positif, namun di sisi lain juga terdapat tantangan yang dihadapi. Dari sisi faktor pasar, penduduk muslim di Indonesia yang merupakan jumlah terbesar di dunia menjadi keuntungan tersendiri. Segmen penduduk muslim tersebut tentunya akan selaras dengan pertumbuhan transaksi digital yang berkorelasi positif pada pertumbuhan industri fintech syariah.

Di sisi lain, walaupun jumlah penduduk Muslim Indonesia besar, terdapat tantangan yang dihadapi karena tingkat literasi digital penduduk Indonesia yang masih relatif rendah sebagaimana Survei Nasional Literasi dan Inklusi Keuangan (SNLIK) yang dilakukan Otoritas Jasa dan Keuangan pada tahun 2019 yang menunjukkan indeks literasi keuangan mencapai 38,03 \%. Namun demikian, jika dibandingkan dengan hasil survei serupa di 2016, diperoleh informasi bahwa dalam 3 tahun terakhir terdapat peningkatan pemahaman literasi keuangan literasi masyarakat sebesar $8,33 \%$. Pemerintah perlu memasukkan kurikulum dan pendidikan terkait ekonomi digital untuk mendukung kesiapan Sumber Daya Manusia (SDM) Indonesia di bidang tersebut.

Dukungan yang Pemerintah berikan untuk mempercepat perkembangan ekonomi digital sudah cukup baik. Namun demikian, regulasi Pemerintah belum mengakomodasi pertumbuhan startup digital yang sangat pesat dan regulasi-regulasi dari berbagai lembaga dirasa kurang harmonis serta belum terkoordinasi dengan baik. Tantangan lainnya dari sisi regulasi di antaranya adalah regulasi terkait perlindungan konsumen di sektor digital yang masih kurang dan terdapat isu-isu cybercrime dan cyberattack yang belum teratasi.

\section{KESIMPULAN}

Usaha Mikro Kecil dan Menengah (UMKM) dapat memanfaatkan fasilitas yang diberikan oleh fintech syariah sebagai alternatif untuk mendapatkan pembiayaan modal usaha di luar pembiayaan konvensional, antara lain perbankan. Selain itu, fintech syariah juga dapat pula mendorong Usaha Mikro Kecil dan Menengah (UMKM) dalam meningkatkan literasi digitalnya dan melakukan pencatatan transaksi keuangan usahanya dengan lebih baik.

Kesadaran untuk melegalkan usahanya juga dapat meningkat karena usaha yang telah berbadan hukum akan memiliki peringkat resiko yang lebih rendah. Dari sisi regulasi, sebagai bentuk dukungan atas perkembangan Usaha Mikro Kecil dan 
Menengah (UMKM) dan juga untuk mewujudkan Indonesia yang bangkit dan kembali tumbuh, Pemerintah perlu fokus untuk menerbitkan kebijakan yang berpihak pada pertumbuhan dan stabilitas ekonomi, terutama bagi perkembangan Usaha Mikro Kecil dan Mengah (UMKM) sebagai tulang punggung perekonomian nasional. Namun, kebijakan Pemerintah tersebut tentunya juga harus mencakup mitigasi terhadap resiko yang muncul akibat perkembangan industri fintech, terutama fintech syariah.

\section{DAFTAR PUSTAKA}

Ardiansyah, M. dan Sawitri, P. 2019. Analysis of Factors that Influence The Use of Social Media by Small and Medium Enterprises. IEEESEM, 7(11), p. 32-41.

Fenwick, M, McCahery, J. A, dan Vermeulen, E. P. M. 2017. Fintech and the Financing of Entrepreneurs: From Crowdfunding to Marketplace Lending. European Corporate Governance Institute, 369, p. 1-53.

Hsueh, S. C. \& Kuo, C.H. 2017. Effective Matching for P2P Lending by Mining Strong Association Rules. In Proceedings of the 3rd International Conference on Industrial and Business Engineering, p. 30-33.

Milian, E.Z., Spinola, M.D.M, dan de Carvalho, M.M. 2019. Fintechs: A Literature Review and Research Agenda. Electronic Commerce Research and Applications, 34. doi:10.1016/j.elerap.2019.100833.

Muzdalifa, Irma., Rahma, Inayah Auliaa., \& Novalia, Bella Gita. 2018. Peran Fintech dalam Meningkatkan Keuangan Inklusif pada UMKM di Indonesia (Pendekatan Keuangan Syariah). Jurnal Masharif alSyariah : Jurnal Ekonomi dan Perbankan Syariah, 3(1). https://doi.org/10.30651/jms.v3i1.16 18.
Ozili, P. K. 2018. Impact of Digital Finance on Financial Inclusion and Stability. Borsa Istanbul Review, 18(4), p. 329-340.

Rizvi, S.K.A., Naqvi, B., dan Tanveer, F. 2018. Is Pakistan Ready to Embrace Fintech Innovation?. The Lahore Journal of Economics, 23(2), p. 152182.

Sharma, Parmendra \& Gounder, Neelesh. 2012. Obstacles to Bank Financing of Micro and Small Enterprises: Empirical Evidence From The Pacific With Some Policy Implications. Journal of Asia-Pacific Development, 19(2), p. 49-75.

Sutarmin, S. \& Susanto, A. 2017. Potensi Pengembangan Transaksi Non Tunai di Indonesia. Sustainable Competitive Advantage (SCA) FEB UNSOED, 7(1), p. 292-302.

Temelkov, Zoran \& Samonikov, Marija Gogova. 2018. The Need for Fintech Companies as Non-Bank Financing Alternatives for SME in Developing Economies. International Journal of Information, Business and Management, 10(3), p. 25-33.

Vasilescu, Laura. 2014. Accessing Finance for Innovative EU SMEs - Key Drivers and Challenges. Economic Review : Journal of Economics and Business, 12(2), p. 35-47.

Wang, Yao. 2016. What are the Biggest Obstacles to Growth of SMEs in Developing Countries? An Empirical Evidence from an Enterprise Survey. Borsa Istanbul Review. 16(3).

Winarto, W.W.A. 2020. Peran Fintech dalam Usaha Mikro, Kecil, dan Menengah (UMKM). Jesya (Jurnal Ekonomi \& Ekonomi Syariah), 3(1), p. 61-73.

World Bank Group. 2020. Leveraging Islamic Fintech to Improve Financial Inclusion. World Bank. 
2021, Jurnal Tabarru' : Islamic Banking and Finance 4 (2) : 412 - 422

World Economic Forum. 2015. The Future of FinTech - A Paradigm Shift in Small Business Finance. Global Agenda Council on the Future of Financing \& Capital. 